\title{
The Emergence of Studio Apartments
}

\section{Mine Ulusoy* \& Merve Özkaynak**}

\section{Abstract}

The first studio-type residences that emerged in America have become widespread throughout the world in the coming years. The studio flourished as an American culture in Turkey, in order to meet the need for single-person living. During the 19th century, immigrants from America and other European countries, mostly from Great Britain and Ireland, have been migrated. The search for solutions to these housing problems has created studio-type apartments. Immigration has resulted in millions of people coming to the media in bad conditions and bringing legal solutions to the agenda. In this study; the sociocultural and architectural qualities of the concept of the studio apartment in America, which is frequently seen in recent years in Turkey, have also been examined.
Keywords: America, studio apartment, Immigration, tenement housing.

*Assoc. Prof. Dr. Faculty of Architecture, Selcuk University, Konya, Turkey. E-mail: mulusoy@selcuk.edu.tr

**Research Assistant, Faculty of Architecture, Selcuk University, Konya, Turkey.

E-mail: merve.ozkaynak@hotmail.com 


\section{INTRODUCTION}

Social, cultural and economic conditions are affecting the needs of the individual. In this interaction, changes are felt in the culture of sheltering. At the beginning of the physical needs, sheltering is constantly changing and developing with the influence of the socio-cultural and economic factors.

Globalization has brought about the diversification of cultural life, and the fact that it is the only person living in America (apart from family), identified with Western culture, has found its place in our culture over time. The desire to live alone resulted in the emergence of a residential model as $1+1$ different from the usual $2+1$ or $3+1$ houses. Nowadays, the number of these houses which are called "studio type" and which is in great demand with the new way of life that follows is quite high today. These studiotype residences first appeared in America.

Social, cultural and economic conditions are affecting the needs of the individual. These changes are being felt in the housing culture interact. At the beginning of the physical needs, sheltering is constantly changing and developing with the influence of the socio-cultural and economic factors.

Globalization has brought about the diversification of cultural life, the fact that it is the only person living in America that is identified with Western culture, and has found its place in our culture over time. The desire to live alone resulted in the emergence of a residential model as $1+1$ different from the usual $2+1$ or $3+1$ houses. Nowadays, the number of these houses which are called "studio type" and which is in great demand with the new way of life that follows is quite high today. These studiotype residences first appeared in America.

The city experience also changes significantly with globalization. The deepening of the gap between the rich and the poor, the diminishing of differences among societies, the spread of consumption cultures, the development of a uniform culture and lifestyle and the emergence of differences, confusion, social polarization are the most obvious effects of globalization on urban life (Yayli, 2012).

In terms of lifestyle, the societies are becoming more and more similar, in other words, "Americanization" (Talaş \& Kaya, 2007). As a result of being integrated with each other's culture is a product of American culture on Turkey in the first $1+1$, which is the largest city in Turkey's construction was begun in Istanbul. Görgülü (2003); mentioned that studio type apartment were designed for the people who separated from the nuclear family and separated from the divorce, the living alone and the young 
people who want to live separately from education or family, and that these new houses are made up of living and living spaces.

According to Oxford Dictionary, studio apartment means a house containing a main room (https://en.oxforddictionaries.com, 2016). Studio type apartments are $1+0$ or $1+1$ housing, consisting of living, sleeping and a bathroom. In the $1+0$ housing, living and sleeping space are designed together and in addition there is a bathroom. In contradistinction to studio type $(1+0)$, in $1+1$ apartments; the living space and the bedroom are separated. In the $2+1$ and $3+1$ houses, the separate toilet and bathrooms merged into $1+0$ and $1+1$, and became the only bathroom.

Although studio-type apartments first appeared in America, they began to spread in other countries over time.

\section{THE EMERGENCE OF STUDIO APARTMENTS}

\section{Great Migrations to America}

De Forest and Veiller (1903) described the great immigration to America: "The migration from 1806 to 1816 during the war period is unusually low. But in 1817, arrivals from foreign countries reached a number of approximately 22,000 immigrants at various unexpected entrances. At that time immigration was mainly from Great Britain and Ireland. In 1820, migrants from these countries had $72 \%$ of all migrations, and a large proportion of them were Irish. By 1827 immigration had increased rapidly and the number of immigrants from all ports registered 3 times since 1817 continued to increase to 1834, which was about 68,000. Important German immigration began in 1834."

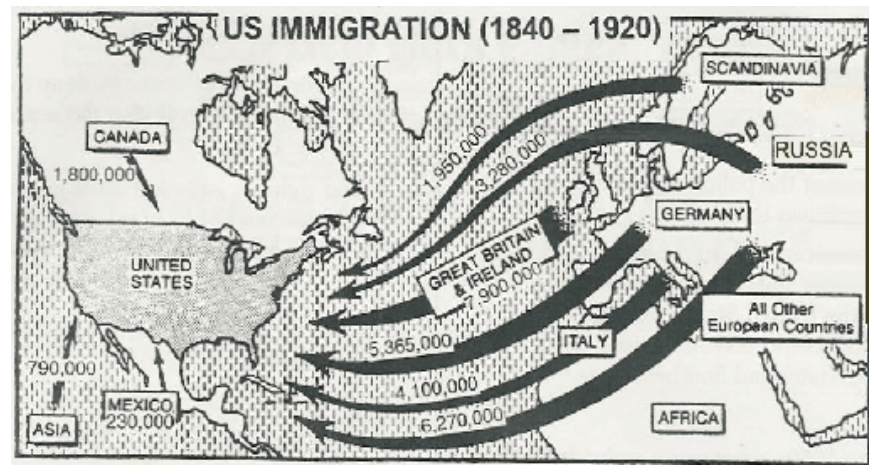

After the 1830s, immigrants to the United States provided the unemployed worker with the necessary skills to cause the country's economy and cities to expand physically (Lubove, 1963). During the first years of the civil war, although immigration had fallen, it increased between in 1863 and 1864 (De Forest \& Veiller, 1903).
Figure 1. Migration to America between1840-1920 (http://ennettsworld.blogspot.com.tr/ 2011/02/immigration-act-of-1924introduction.html, 2011) 
The migration to America has been the largest population movement ever known. Approximately 26 million people have emigrated to America since 1820. The number of those between 1870 and 1905 has doubled. In 1906 1.100.735, in 1907 1.285.349 and in 1908732.870 people migrated. About 6 million of 26 million people have come in the last 6 years (Edwards, 1909).

Figure 2. Immigration to America between 1820 and 1860 (www.latinamericanstudies.org, 2016)
Figure 3. Tenement Blocks of New York's East Area in 1900 (Veiller, 1903)

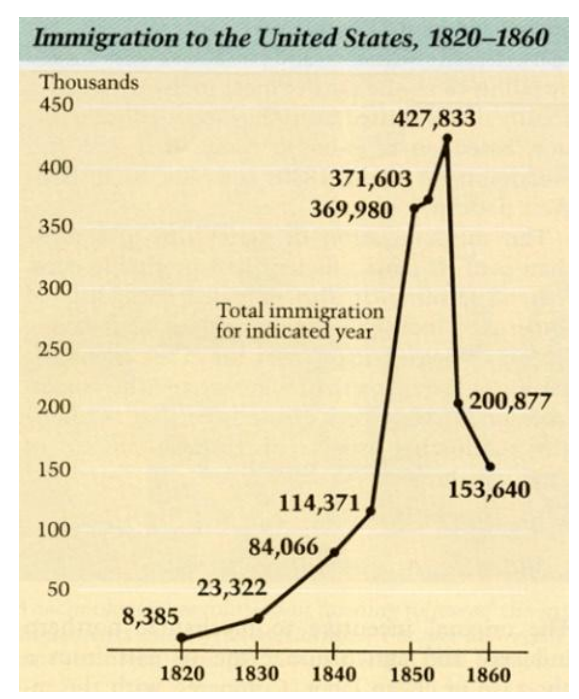

O'Rourke (1995); in his article "Immigration and Living Standards Since famine in Ireland"; The most important of the crises of Western Europe history is the Irish Potato Shortage, which was in 1845-1849. In O'Rourke (1995); mentioned that when 1.5 million people left Ireland before the famine, the immigration from Ireland suddenly rose after the famine, and the population of 8.2 million in 1841 fell to 4.4 million in 1911 and a total of about 60 million people in America between 1820 and 1914.

\section{Tenement Housing in America}

America's immigration has come to an end in the need for extraordinary housing. In the first place, it has been tried to be solved with tenement housing.

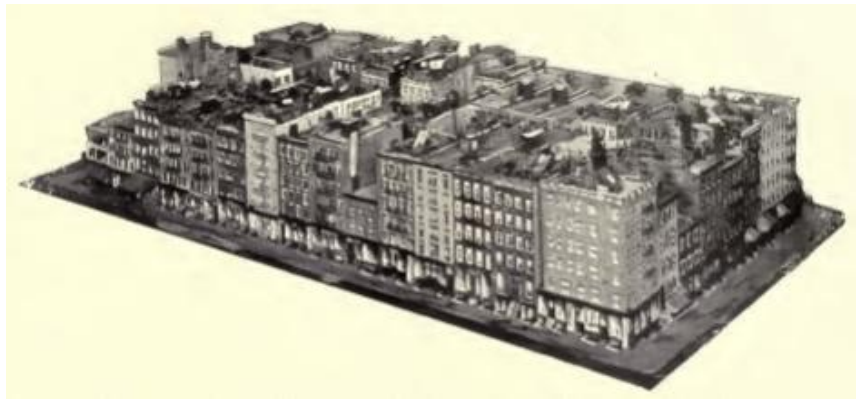


According to Veiller (1903), it is not known when the first tenement housing was built in America. From about 1830 to about 1900, almost all of the tenement housing were built in New York, almost all of them bad. These houses are dub-bell types, with a solid straight railway type with no light clearance, the second with very narrow shafts that provide virtually no ventilation to poor rooms and practically no light (Murphy, 1915).

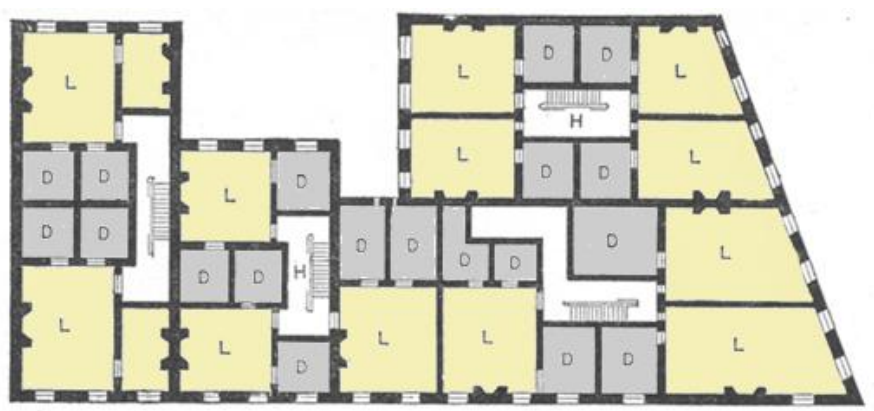

TENEMENT OF 1863, FOR TWELVE FAMIL IES ON EACH FLAT 2D. dark L. light. H. halls

Tenement Housing Plan Types

Three plan types of tenement houses were examined in this section.

First type; a typical tenement housing drawn by W. D. AUSTIN (Collins, 1904); It consists of four floors. This type of ground floor consists of three $1+0$, the upper floor consists of one $1+1$, two $1+0$. There is only one toilet on each floor, but no bathrooms. In the first plan type $1+0$, the air shafts were opened to allow the room to receive light. This plan type $(1+0)$ consists only of living space. The second plan type $(1+1)$ consists of living room and bedroom.

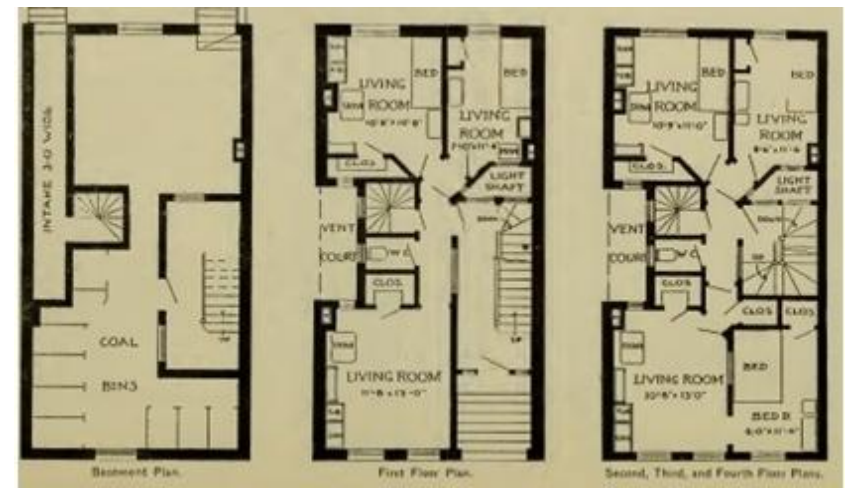

Second type; tenement housing cornered by W. D. AUSTIN (Collins, 1904); It consists of five floors. This type of 4 side is surrounded by road and is resolved as 4 blocks. Room types are
Figure 4. Tenement Housing in 1865 in America (Riss, 1890; www.latinamericanstudies.org, (2016)

Figure 5. First Plan Type (Collins, 1904) 
$1+1$ or $2+1$. Light shafts were opened as a solution for the rooms to take light. There is only one toilet on each floor, but no bathroom. Organizing the rooms is quite simple. There is no hol yet, and there are transitions between rooms. This plan type is a very common tenement housing in America.

Figure 6. Second Plan Type (Collins, 1904)
Figure 7. Third Plan Type (Collins, 1904)

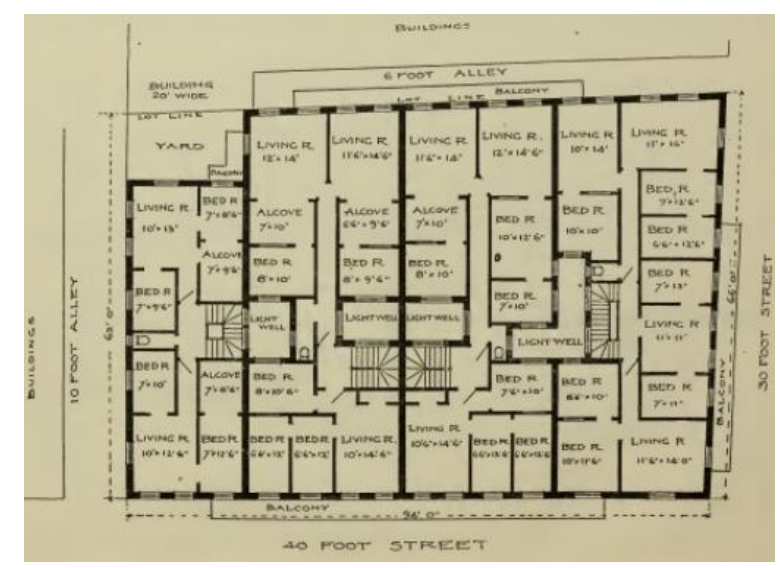

Third type; another tenement housing drawn by W. D. AUSTIN (Collins, 1904); It consists of 4 floors. Considering the floor plans of this type, there are three $1+1$, four $2+1$ on each floor. There are 4 stairs in total. Each apartment has a toilet that can be reached from inside the living area. Unlike other dwellings, living spaces and bedrooms can light.

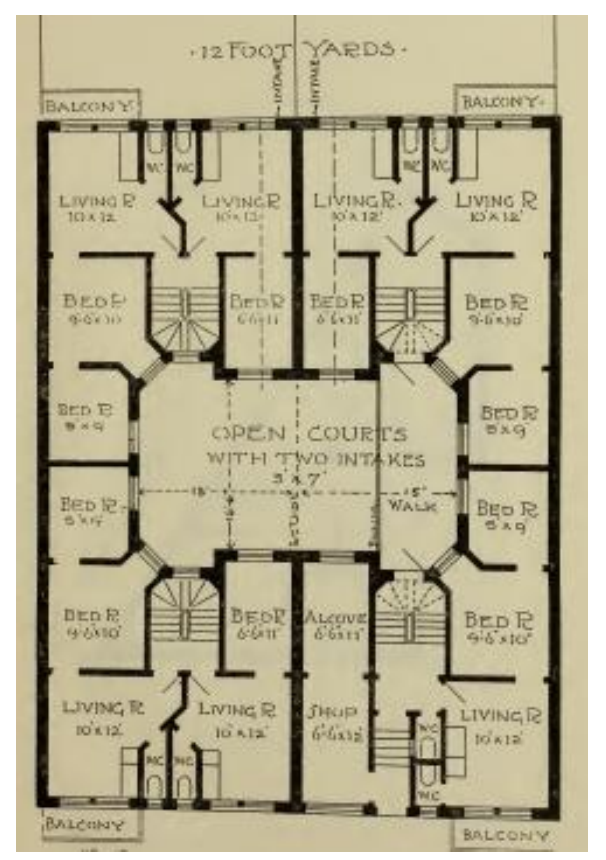

The Assessment of Qualifications of Tenement Housing

Since 1842 , the $1+1$ housing system for rent has grown due to the increasing migration. In 1864, the number of New York immigrants was 486.000 , while the number of tenement housing was 15.511 , while in the same city in 1900 , the number of 
immigrants rose to 1585 and the number of tenement housing increased to 42.700 (De Forest \& Veiller, 1903).

In 1900, more than 80,000 homes were built in New York and about 2.3 million of the total population of about 3.4 million homes were home to a population of two-thirds (http://www.history.com/topics/tenements, 2016).

Gallatin (1880); He explained that tenement housing in New York should be examined and that this tenement housing system is referred to as a disease called "the rotting of tenement housing ", and that the search for the cause of this disease and finding a solution would be the most useful job for the city.

In the book "Report of Civics Committe" (1912) by Chicago Woman's Club and "How The Other Half Lives" by Jacob RISS (1890), the problems of New York's tenement housing are described. The problems of tenement housing reflected in the media. In the "Report of Civics Committee" (1912) citizenship committee report prepared by Chicago Woman's Club, the current conditions of tenement housing have been examined. In this report, the bad situation of the houses and the streets in which they are located has been identified. According to this report; It is told that the garbage is poured into the streets, the narrow roads are full of wastes, half of the examined structure is dark, there are no windows in the part used as bedrooms, iron fire escapes are not available and the situation which is not suitable for the living is quite grave. In each building 90 people and their 50 children have taken into consideration that the houses in which they live together are in such a bad condition that they can not survive, and they have prepared a report that children have skin diseases and that there are more than 4 people in single rooms.

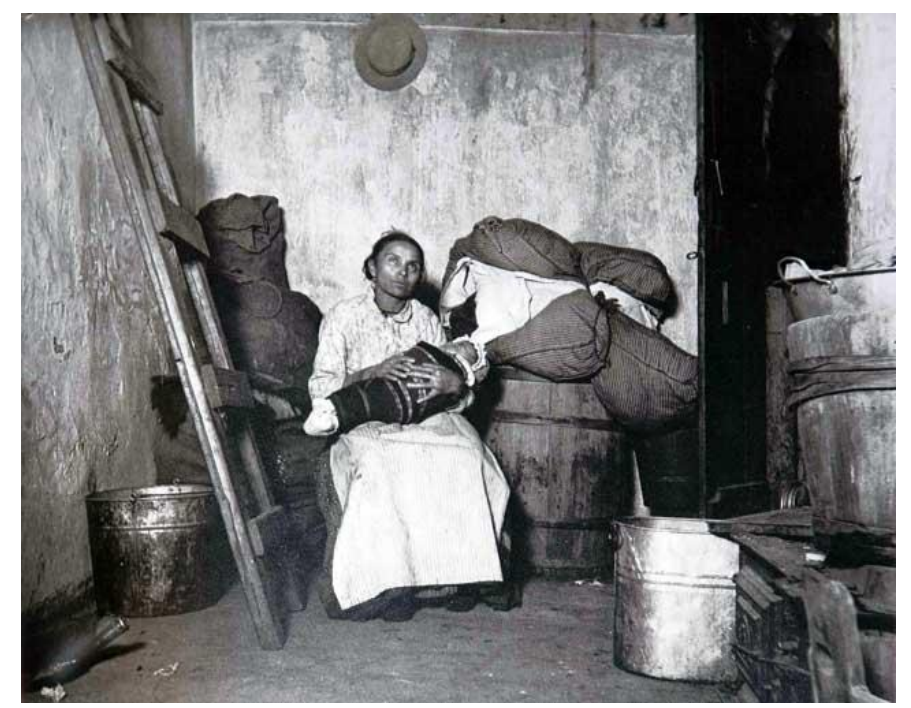

Figure 8. Tenements Living in Bad Conditions (Riss, 1890) 
The problems of tenement housing, which are the result of increasing immigration to the United States, are increasing crime rates, increasing environmental damage, increasing poverty, degrading standard living standard and various diseases. As a result of the reflection of these problems in the media, many public institutions have decided to go for improvement in these buildings.

\section{Establishment of "Tenement Housing" Commission in 1901 and Tenement Housing Museum}

As a result of the reflections and awareness of the media, in 1865 the hygiene council made the first act for tenement housing. The first step was the establishment of the metropolitan health board in 1866 and the act of tenement housing the next year.

With the movement that began in 1865, the 1901 law was enacted in America and the definition of tenement housing was made:

"A tenement house is any house or building, or portion thereof, which is rented, leased, let or hired out, to be occupied, or is occupied as the home or residence of three families or more living independently of each other, or doing their cooking upon the premises, or by more than two families upon any flor, so living and cooking, but having a common right in halls, starways, yards, water-closets or privies, or some of them." (Fryer, 1901).

This law has become essential in every building fire escape. Article 29 mentions:

"Every now existing non-fireproof tenement house, unless provided with fireproof outside stairways directly accessible to each apartment, shall have fire escapes located..." (Fryer, 1901).

As a result of the decisions taken at the commission, an out-ofwindow requirement has been introduced to prevent dark rooms:

"In very tenement house hereafter erected the total window area in each room, expect water closet compartments and bathrooms, shall be at least one-tenth of the superficial area of the room. " (Fryer, 1901).

The 1901 Tenement House Act has begun to see many changes in tenement housing. In the bedroom rooms the windows became obligatory and the solution to the dark room was found. 


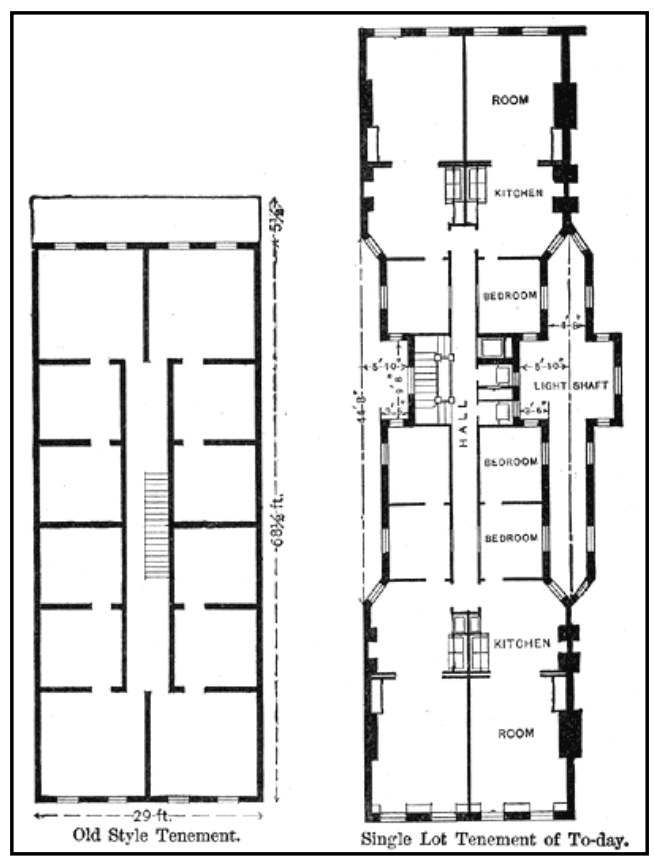

The first studio apartments that were built for the people who came to America with immigration were now turned into museums.

In 97. Orchard's Street the tenement housing, more people lived than people living in 20 countries from 1863 to 1935, was purchased by Ruth J. Avram in 1966. This housing was restored in 1988 as a tenement housing museum describing different periods of migration (http://www.nytimes.com, 2013).

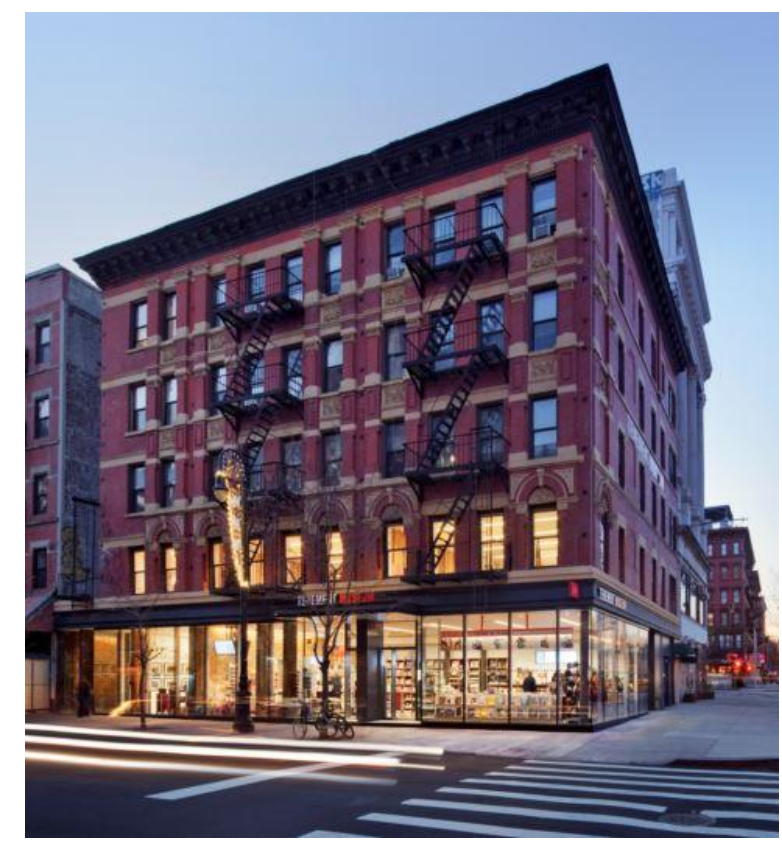

Figure 9. An Old Style Tenement Housing and Tenement Housing Building after the Law
Figure 10. Tenement Housing Museum (https://www.tenement.org, 2014) 
Figure 11. Tenement Housing Museum (http://www.nytimes.com, 2013)

Figure 12. Tenement Housing Museum (http://www.nytimes.com, 2013)
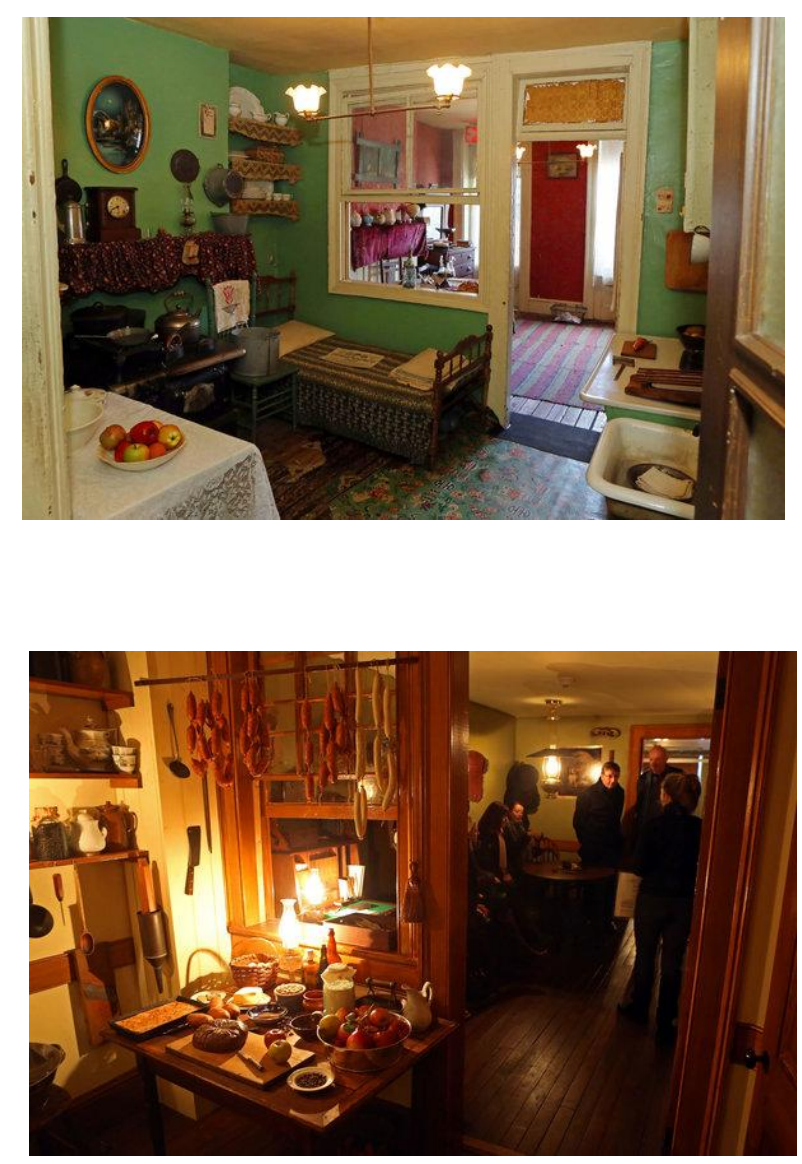

\section{CONCLUSION}

In this study; how the studio-type houses first appeared, the reasons for the first construction in the history and the first users were investigated. In the 19th century, there were three major migrations to America. These great migrations; one from Great Britain and Ireland, the second from other European countries such as Russia, Poland and Italy, and the third from China. As a result of these three migrations, about 26 million people came to America.

Among the first problems of immigrants are unemployment and housing problems. The settlement solution has been found with one room and these houses have caused many problems. Problems such as the lack of open windows, the lack of light and air, the lack of water for cleaning, the emergence of various diseases, and the high rates of crime are reflected in the media, and as a result, legal regulations are required.

In the study, a general plan type and three sample plan types of tenement housing were examined. Many problems, such as dark rooms in these plan types, have been tried to be solved by improving with legal regulations. "The Tenement Housing Act" came into action in 1901. A new plan type has emerged as a 
result of the legislation, which requires a window to be opened outdoors in the living room and in bedrooms to prevent light and air problems. Today these housing are used as museums.

Studio-type residences that emerged as a result of American culture; Turkey was made as a necessity. Today, these buildings are in demand by students, single living persons and newly married couples who are studying separately from their families. Studio type residences; especially Konya, Eskisehir, such as the student population, was made.

\section{Acknowledgement}

This study is based on the master's thesis titled "Development of Studio Apartments: The Case of Konya" prepared by Merve Özkaynak in partial fulfillment for the master' degree at Selcuk University Graduate School of Sciences. Konya, 2016 (Advisor: Assoc. Prof. Mine Ulusoy)

\section{REFERENCES}

Collins, A. (1904). Report of The Commission to Investigate Tenement-House Conditions. Retrieved from Boston:

Committee, C. (1912). Tenement Housing Conditions in Twenteth Ward. Retrieved from Chicago:

De Forest, R. W., \& Veiller, L. (1903). The Tenement House Problem: Including The Report Of The New York State Tenement House Commission of 1900 (Vol. 2). New York: Macmillan.

Edwards, R. H. (1909). Immigration Studies In American Social Conditions-3. Madison, Wisconsin: Harward College.

Fryer, W. J. (1901). The Tenement House Law Of The City Of New York. New York: The Record And Guide.

Gallatin, J. (1880). The Tenement-House Reform in The City of New York. Retrieved from

Görgülü, T. (2003). İstanbul'da Çeşitlenen Konut Üretim Biçimleri ve Değişen Konut Alışkanlıkları. mimar.ist, 3(7), 50-56.

http://ennettsworld.blogspot.com.tr/2011/02/immigration-actof-1924-introduction.html. (2011).

http://www.history.com/topics/tenements. (2016).

http://www.nytimes.com. (2013).

https://en.oxforddictionaries.com. (2016).

https://www.tenement.org. (2014).

https://www.latinamericanstudies.org. (2016).

Lubove, R. (1963). The Progressives And The Slums: Tenement House Reform In New York City, 1890-1917 Retrieved from http://www.library.pitt.edu/digital-researchlibrary

Murphy, J. J. (1915). The Tenement House Department. Proceedings of the Academy of Political Science in the City of New York, 5(3), 44-46. 
O'Rourke, K. (1995). Emigration And Living Standards In Ireland Since The Famine. Journal of Population Economics, 8(4), 407-421.

Riss, J. (1890). How The Other Half Lives:Studies Among The Tenements of New York. New York: Charles Scribner's Sons.

Talaş, M., \& Kaya, Y. (2007). Küreselleşmenin Kültürel Sonuçları. Tübar(22), 149-162.

Veiller, L. (1903). Tenement House Reform in New York City, 1834-1900. The Tenement House Problem, 1, 69-118.

Yaylı, H. (2012). Küreselleşmenin Kentler Üzerine Etkisi: "İstanbul Örneği". SÜ IIBBF Sosyal ve Ekonomik Araştırmalar Dergisi(24), 331-355.

\section{Resume}

Mine Ulusoy, She graduated from Selcuk University, Engineering and Architectural Faculty in 1986. In 1992, she received master's degree in Selcuk University, Department of Architecture. She completed her doctorate in Selcuk University, Department of Architecture, with a thesis entitled "Historical Development of Apartment Constructions in Konya". In 1987 she worked as an Research Assistant at Selcuk University, Faculty of Engineering and Architecture, Department of Architecture. She has been working in Selcuk University as an associate professor department of Architecture.

Merve Özkaynak, She graduated from Selcuk University, Architectural Faculty in 2014. In 2014, she has begun master's degree in Selcuk University, Institute of Science, Department of Architecture. In 2016 she worked as an research assistant at Selcuk University, Faculty of Architecture, Department of Architecture. She has been working in Selcuk University as an academic staff of department of Architecture. 